\title{
EMULAÇÃO E INTERTEXTUALIDADE EM PARA AONDE MARCHA O BRASIL? (1978), POR FERNANDES BARBOSA ${ }^{1}$
}

\section{EMULATION AND INTERTEXTUALITY IN PARA AONDE MARCHA O BRASIL? (1978), BY FERNANDES BARBOSA}

Ellen dos Santos Oliveira ${ }^{2}$

RESUMO: Este artigo analisa a obra Para aonde marcha o Brasil? de Fernandes Barbosa, publicada em 1978, durante o período da Ditadura civil-militar no Brasil (1964-1985). Trata-se de uma obra de respostas às poesias satíricas do bispo Dom Pedro Casaldáliga, lidas e relidas por Fernandes Barbosa em duas publicações: Tierra nuestra, liberdad, e Yo creo en la justicia y en la esperanza. Nossa análise tem como metodologia a Literatura Comparada e foi orientada pelos conceitos de emulação e intertextualidade. O objetivo neste trabalho é analisar como as representações identitárias em Para aonde marcha o Brasil? (1978) encenam um jogo discursivo de representação dos "eus - líricos", Fernandes Barbosa e João do Adro, nas vozes híbridas que compõem o conjunto textual da obra.

PALAVRAS-CHAVE: Literatura brasileira; Fernandes Barbosa; João do Adro.

AвSTRACт: This article analyzes the work Para aonde marcha o Brasil? by Fernandes Barbosa, published in 1978, during the period of the civil - military dictatorship in Brazil (19641985). It is a work of answers to the satirical poetry of Bishop Dom Pedro Casaldáliga, read and reread by Fernandes Barbosa in two publications: Tierra nuestra, liberdad, e Yo creo en la justicia y en la esperanza. Our analysis was based on Comparative Literature and was guided by the concepts of emulation and intertextuality. The objective of this work was to analyze the identity representations in Para aonde marcha o Brasil? (1978) stage a discursive game of representation of the "lyrical selves", Fernandes Barbosa and João do Adro, in the hybrid voices that make up the textual set of the work.

KEYwords: Brazilian literature; Fernandes Barbosa; João do Adro.

\footnotetext{
${ }^{1}$ O presente trabalho foi realizado com apoio da Coordenação de Aperfeiçoamento de Pessoal de Nível Superior - Brasil (CAPES) - Código de financiamento 001.

${ }^{2}$ Doutora em Letras pela Universidade Federal de Sergipe (UFS), membro do Centro Internacional e multidisciplinar de Estudos Épicos da UFS (CIMEEP-UFS). E-mail: profa.ellen.oliveira@live.com.
} 


\section{INTRODUÇão}

Em 1978, em meio a uma ditadura civil-militar (1964-1985), Fernandes Barbosa esboça a pergunta Para aonde marcha o Brasil? (1978), questionamento semelhante ao que Carlos Drummond de Andrade fez ao seu personagem "José" do poema E agora, José?, provavelmente escrito em 1945. Fernandes Barbosa (1978), à medida que indaga, anuncia ao leitor que o Brasil continuava marchando. Sua sátira, em forma de discurso e poesia, evidencia o destino incerto de um país no qual se situava dividido entre a marcha do Exército militar brasileiro e a marcha do comunismo, no período da Ditadura civil-militar (1964-1985), registrando sua resistência e militância política e ideológica escrita em protesto e lavrada em libelo. Nesse contexto ditatorial, Para aonde marcha o Brasil? (1978) é um exemplo dessa representação (e repressão) política, ideológica e literária, da época ditatorial. Assim, o espaço literário é um lugar privilegiado de poder pelo qual o poeta luta para exercê-lo.

Nilo Fernandes Barbosa (1910-1988), além de ser reconhecido como o "Poeta da cidade", pois escrevia sobre tudo que via na cidade e além dela, alcançou destaque no cenário político e literário por seus hábeis discursos e sua atuação crítica sobre questões políticas de seu tempo. Savi (2002), ao testemunhar sobre o poeta Nilo Fernandes Barbosa e sua irritação em relação aos fatos e feitos políticos, assim diz:

Disse de sua irritação contra a política, enxergando além do horizonte, sobretudo identificando esta vergonha nacional em rimas mordazes, verberou o abandono do homem agrícola.

Articulista de debates, tomou posição clara e firme frente à maioria de nossos problemas. Foi homem exemplar e amigo, usou da lealdade em seu convívio (SAVI, 2002).

Nota-se que é tomando posição, ou posições, que Fernandes Barbosa se comporta não só no dia a dia - com amigos, familiares e públicos em geral - mas, também, adentrando-se no espaço literário, pois esse é o seu lugar e entre lugar de poder e onde ele exercita seu engajamento político e literário, militando em sua crença e fé, compartilhada em público, seja através de seus discursos ou através da literatura. Considerando o exercício da linguagem como um exercício de poder e de uso político.

Nesse sentido, entende-se seu engajamento no espaço literário como um exercício intelectual e artístico em um entre-lugar, pois seu discurso se situa entre seus dois "eus-líricos" que atuam como dois opostos e cujas identidades são negociadas por meio da linguagem. Assim, sob a ótica do Fernandes Barbosa ambos os "eus" funcionam como uma crase fundamental. Já sob a ótica do João do Adro, o Fernandes Barbosa é o girondino, e o João do Adro é o jacobino. Dessa forma, o Nilo Fernandes Barbosa pode ser definido como um terceiro, ou um sujeito híbrido, e sua literatura serve como uma demonstração do homem dividido entre esses dois opostos políticos, numa tentativa de amenizar os extremos. 
Sua obra revela a força da linguagem, em especial na literatura, não apenas como uma representação simples do real, mas, também, da demonstração da realidade tal como explica Roland Barthes (2013), que não se refere ao poeta Nilo Fernandes Barbosa, mas à questão do real, ao dizer que embora o real não seja representável, ele é demonstrável. E essa função da literatura como demonstração do real é uma função utópica, pois na literatura reencontramos a História, e nela se concebem utopias da linguagem que revelam um novo profetismo, como se o escritor através da literatura assumisse uma missão de "mudar o mundo" (BARTHES, 2013, p.23). Portanto, podemos dizer que a produção do poeta ao admitir tal missão o faz com base na demonstração da realidade do cenário sócio-político no século XX, a partir da encenação lírica desses dois "eus- líricos" que, de certo modo, são metáforas do cidadão brasileiro: de um lado, o girondino, o democrata cristão representante dos ruralistas; e do outro, o jacobino, de atuação mais satírica e direta, dele encontramos poemas satíricos que foram publicados em Jornal do Povo e, depois, reunidos na obra Esboço de uma época (1987).

Foi assumindo a literatura como missão que Nilo Fernandes Barbosa (1910-1988) concebeu toda a sua produção literária3. Para aonde marcha o Brasil? (1978) integra a produção literária e política do poeta gaúcho Nilo Fernandes Barbosa (1910-1988), constituindo-se como valioso arquivo histórico sobre o século XX, de relevante valor histórico e literário que, ao ser estudado, pode levar à compreensão do cenário crítico nos quais suas obras foram concebidas e, ainda, serve como encenação de representações ideológicas opostas, mediadas pela visão crítica do intelectual que se coloca acima dos fatos e dos partidos, lançando um olhar globalizante que enxerga além das fronteiras, a fim de entender, a partir de uma percepção e captação críticas, a gênese das coisas e o caminho que mais lhe parecia apto a seguir, mesmo que, às vezes, esse caminho pareceu contraditório, pois foi nele onde caminharam juntos seus "eus" na encenação criativa de si, do outro e do mundo.

Para aonde marcha o Brasil? foi concebido em $1978^{4}$ fundamentado na leitura e recepção crítica de duas obras das quais os poemas do atuante esquerdista comunista, o bispo São Felix da Araguaia, são extraídos: Tierra nuestra, liberdad, e Yo creo en la justicia y en la esperanza. Trata-se

\footnotetext{
${ }^{3}$ Conforme o mapeamento que fiz da produção literária do poeta, constata-se: Frutinha proibida (1938), Minhas flores de Jacarandá (1944), Os 'gatos' e o remédio (1949), Carreirada (1954), Figurinhas do Bazar (1956), Noite Feliz (1958), Súplica ao Negrinho do Pastoreio (1959), Cretino é quem toma de uma enxada (1960), Sepé - o morubixaba rebelde (1964), Para aonde marcha o Brasil? (1978), Tradição Relambória (1984), Preto e branco (1986), Trovas ao vento (1986), Esbộco de uma época (1987); quatro contos - A alma do pai tá de acordo?..., Crime e sentença, Tirada de castelhano, e O preço de um pecado; crônicas - Flor agreste brotada na pedra, O engolidor de caminhos, além de mais de uma centena de poemas espessos e inéditos, datilografados e manuscritos (OLIVEIRA, 2016, 107).

${ }^{4}$ No mesmo ano em que Para aonde marcha o Brasil? (1978) foi publicado, de acordo com Regina Zilberman (1980), foi registrado nas Letras da História da Literatura Brasileira, obras de: Autran Dourado, Armas e corações; Gilberto Mendonça Telles, Poemas reunidos; Afonso Romano de Sant'Anna, A grande fala do índio guarani. Já, no cenário das Letras do Rio Grande do Sul, Zilbermam (1980) apresenta: Antônio Carlos Resende, Magra, mas não muito, as pernas sólidas, morenas; Deonísio da Silva, Mesa dos inocentes; Josué Guimarães, Dona anja e enquanto a noite não chega; Luis Antonio de Assis Brasil, A prole do corvo; Moacyr Scliar, Dr. Miragem; Sergio Faraco, Hombre; Carlos Nejar, O chapéu das estações; Barbosa Lessa, Rodeio dos ventos; Flávio Aguiar, os caninos do vampiro; Tania Faillace, Tradição família e outras histórias; Armindo Trevisan, O ferreiro harmonioso (ZILBERMAN, 1980, 167-168).
} 
de uma cartilha - como chamou o jornalista do Jornal do Povo, como veremos mais adiante - ou protesto e libelo - como foi confessado pelo Fernandes Barbosa (1978, p. VIII), em que o ato de criação parte de uma relação de dependência, muito comum na literatura, considerando que toda obra se origina a partir de outra e/ou outras.

Nesse caso, Fernandes Barbosa não apenas lê os poemas do bispo Dom Pedro Casaldáliga, como também os traduz do castelhano e comenta sob a ótica do olhar híbrido dos eu-líricos girondino e jacobino. Trata-se de termos extraídos pelo poeta Nilo Fernandes Barbosa do contexto da Revolução Francesa, no século XVIII, e incorporados em seu projeto literário. Assim, o Fernandes Barbosa representa o Girondino, e o João do Adro o Jacobino. Além dos termos, o poeta também resgata as ideias liberais de "igualdade, solidariedade e fraternidade", considerando o contexto sócio-político no século XX, e, assim, fazendo uma releitura crítica das relações humanas e seus posicionamentos ideológicos.

A ideia de "Cartilha" nos remete à cartilha ou Manifesto comunista, de Karl Marx e Friedrich Engels, publicado originalmente em 1948. O manifesto defende a luta de classe, sob o argumento de que:

A burguesia não pode existir sem revolucionar constantemente os instrumentos de produção, portanto as relações de produção, e por conseguinte todas as relações sociais. A conservação inalterada dos antigos modos de produção era a primeira condição de existência de todas as classes industriais anteriores. A transformação contínua da produção, o abalo incessante de todo o sistema social, a insegurança e o movimento permanentes distinguem a época burguesa de todas as demais. As relações rígidas e enferrujadas, com suas representações e concepções tradicionais, são dissolvidas, e as mais recentes tornam-se antiquadas antes que se consolidem.

Tudo o que era sólido desmancha no ar, tudo o que era sagrado é profanado, e as pessoas são finalmente forçadas a encarar com serenidade sua posição social e suas relações recíprocas (MARX; ENGELS, 2008, p. 15-16).

Na ideologia de Marx e Engels parece não haver espaço para o diálogo entre essas duas classes historicamente antagônicas, uma vez que a burguesia acaba demonstrando-se como a grande opressora da classe operária. Nesse sentido, o comunismo, com sua posição extremista, acabou se revelando como uma ameaça, inclusive, ao pequeno burguês ou aos pequenos proprietários rurais.

Apresentando uma discussão crítica, Para aonde Marcha o Brasil? fala em nome desses proprietários rurais com o intuito de propor um debate intelectual, a fim de conciliar essas duas classes consideradas pelos intelectuais políticos do comunismo como antagônicas. 
Vejamos a pergunta do repórter do Jornal do Povo (1981) e a resposta de Fernandes Barbosa:

JP: O senhor inclusive já editou, às suas custas, uma cartilha contra o Comunismo. Que tipo de regime defende, afinal?

FERNANDES BARBOSA: Se já editei, como você diz e é bem verdade, uma cartilha contra o comunismo, é lógico que com algumas ressalvas, defendo o regime oposto: a liberal democracia. Não essa democracia que muitos confundem com anarquia, e que, por ser democracia é obrigada a respaldar a incoerência, o desrespeito, a desordem, a rebeldia, com greves encomendadas e fomentadas, a cada passo, por eternos caçadores de votos. Indivíduos que pouco se preocupam que se quebre o ritmo de trabalho nas fábricas, que se esfacele a economia nacional. Vale tudo desde que se comprometa o Governo, desde que se desmoralize a situação, desde que se abalem os alicerces das instituições, pela boa fé e ingenuidade do povo, o eldorado de um cargo eletivo Eldorado que a ambição desenfreada andou à cata, embora sabendo que deixou para trás, entre as sementes do falso trigo democrático que semeou, o picão, o pega-pega do comunismo materialista e ateu (FERNANDES BARBOSA, 1981).

Observa-se na fala do poeta a crítica às consequências elencadas pelos movimentos de lutas de classes, defendida por Marx em seu manifesto, tais como "desordem", "desrespeito", "rebeldia", "greves encomendadas e fomentadas", ou seja, uma crítica ao comunismo que atuava de forma mais agressiva no século XX, apresentando a luta de classes como "dois grandes inimigos", a burguesia e o proletariado (MARX; ENGELS, 2008, p. 11).

Nesse sentido, sob a ótica do poeta, essa oposição extremista de inimizade entre as classes gerava desordem e impedia o diálogo entre "patrão" e "empregado", e, ainda, deram origens ao anarquismo, gerando o embate direto com as forças armadas do exército brasileiro, que agiu com discurso de oposição ao comunismo. Assim, o poeta elaborou seu "libelo" fazendo uma leitura crítica dos poemas do bispo comunista D. Pedro Casaldáliga, tomando-o como exemplo de discurso comunista extremista. Vejamos agora a capa da primeira edição de Para aonde marcha o Brasil?. 
Figura 1 - Capa da primeira edição autografada de Para aonde marcha o Brasil? (1978).

\section{PARA AONDE MARCHA}

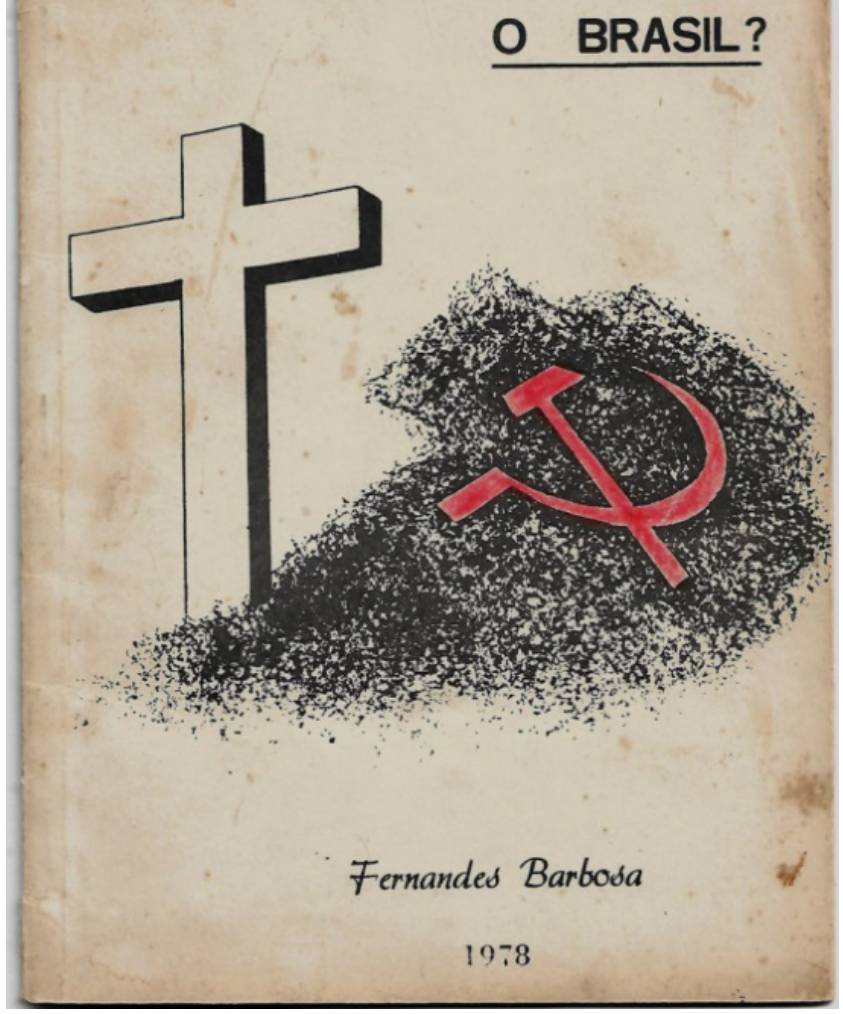

Fonte: Original do autor Fernandes Barbosa (1978).

Observa-se, na capa, a cruz, cujo simbolismo religioso remete à igreja cristã, e vários rabiscos pontilhados pretos em xilogravura, sugerindo a imagem de aglomeração de pessoas em forma de navio, com a foice e o martelo, símbolo do Partido Comunista. Tal imagem remete à importação e à exportação do marxismo dentro e fora das igrejas.

Em relação aos aspectos estruturais da obra, ela divide-se em duas partes não nomeadas: a discursiva, em que Fernandes Barbosa (1978) se dedicou à análise crítica da poesia do bispo Dom Pedro Casaldáliga, fazendo um panorama da divulgação do comunismo dentro das igrejas, por meio do movimento Teologia da Libertação; e a poética que dialoga com a primeira parte discursiva, na qual o eu-lírico emula as poesias do bispo, respondendo-o de forma criativa e poética. Nesse sentido, entende-se a emulação como uma ideia de criação a partir de outra obra, evidenciando o impulso artístico de rivalizar e/ou responder crítica e criativamente, e, nesse caso, o poeta também exervita a militância intelectual e política no processo de escritura. 
Além dos intertextos identificáveis em Para aonde marcha o Brasil? (1978), percebe-se a intertextualidade intergenérica com os famosos Sermões do Padre Antônio Vieira (1608-1697), conhecido pelo seu estilo conceptista - por dar ênfase na retórica e encadeamento lógico de ideias -, dividido em três partes: introdução ou exórdio, desenvolvimento ou argumento e conclusão ou peroração. Conforme, geralmente, são apresentados nos sermões.

Deste modo, podemos dizer que a obra citada de Fernandes Barbosa dialoga não com um sermão específico do referido padre, mas com o gênero literário "sermão" que esse praticou no século XVII. Nesse sentido percebe-se o que Koch, Bentes e Cavalcanti (2007), baseando-se em Marcuschi (2002), defendem como intergenericidade ou intertextualidade intergenérica, cuja forma textual possui uma configuração híbrida, uma vez que corresponde a um "gênero que exerce a função de outro" e, com isso, "revela a possibilidade de operação e maleabilidade que dá aos gêneros enorme capacidade de adaptação e ausência de rigidez" (MARCUSCHI, 2002 apud KOCH; BENTES; CAVALCANTI, 2007, p. 64).

De modo semelhante ao gênero "sermões", é apresentado o discurso ou sermão de Fernandes Barbosa em relação a sua leitura da obra poética do bispo: na primeira parte, temos o exórdio e a argumentação; e, na segunda parte, temos a peroração em três poemas - repostas de cunho satírico bem ao estilo gregoriano, mas sob a ótica do poeta do século XX que reage diante dos fatos contemporâneos.

\section{VOZES QUE MARCHAM ALÉM DO EXÓRDIO E DA ARGUMENTAÇÃO SATÍRICA}

A parte em que cabe o exórdio e a argumentação retórica de Fernandes Barbosa se desenvolve em onze parágrafos, ou doze contando com o parágrafo final da nota explicativa sobre a localização geográfica da poesia do bispo Dom Pedro Casaldáliga. E já que o jogo discursivo entre política e religião, o simbolismo do número doze na Bíblia da tradição judaico-cristã nos remete ao número das doze tribos de Israel, assim os doze parágrafos podem sinalizar uma referência à voz do povo de Deus, ou seja, dos cristãos representados por Fernandes Barbosa, estabelecendo uma espécie de diálogo e confronto com os comunistas.

O primeiro parágrafo tem a função de introduzir afirmativas que serão desenvolvidas em todo o seu "protesto" ou "libelo". Observa-se que ele é iniciado com a conjunção subordinativa condicional "se", demarcando a condição subordinada do orador diante das circunstâncias históricas. Vejamos:

Se as autoridades responsáveis pela segurança nacional, pela salvaguarda de nossas instituições - principalmente as Forças Armadas - não procurarem imediatamente, e com mão de ferro, sufocar, esmagar, a desenfreada, extensiva e ostensiva propaganda comunistóide, que verdadeiros fariseus, do estofo e do quilates do bispo de São Félix do Araguaia, 
Mato Grosso, D. Pedro Casaldáliga, vêm fazendo, promovendo, dentro das igrejas, como também acontece aqui, na Matriz da minha cidade, é fácil a qualquer pessoa, embora de mediana cultura, porém dotada de bom senso, responder a pergunta, dizendo exatamente para aonde marcha o Brasil, se continuar a trilhar o caminho por que vai, tendo, como um de seus vaqueanos e batedores, a figura guevareana do bispo de São Felix do Araguaia (FERNANDES BARBOSA, 1978, I, grifo meu).

Tem-se, na dimensão explícita do discurso, o destinatário que se dirige explicitamente às "autoridades responsáveis pela segurança nacional” ou "Forças Armadas" e insinua a forma com que o destinatário pátrio agia: "com mão de ferro". Em seguida, o orador dá um panorama da ação comunista que, como ele diz, vinha sendo difundida de forma "desenfreada", "extensiva" e "oxtensiva”, direcionando a sátira ao bispo Dom Pedro Casaldáliga, de São Felix do Araguaia, denunciando a pregação do marxismo dentro das igrejas, situando, geograficamente, o local onde ocorria essas pregações: o Mato Grosso e Cachoeira do Sul - RS.

Ainda no mesmo parágrafo, em negrito, temos uma contradição quando ele diz "é fácil a qualquer pessoa" e, depois, em aposto explicativo, diz “embora de mediana cultura", isto é, se a pessoa é de "mediana cultura" ela não é "qualquer pessoa", e a contradição continua quando diz "porém dotada de bom senso", isto é, ter senso crítico. Além disso, "senso" também sugere a censura do período ditatorial, podendo ser considerada uma crítica implícita ou advertência aos poemas do bispo Dom Pedro Casaldáliga. Assim dizendo, o orador orienta que, além de ter "mediana cultura", a pessoa precisaria ser "dotada de bom senso", para poder responder à pergunta dizendo exatamente "para aonde marcha o Brasil?". Assim, observa-se que na visão do poeta, deveria ser uma pessoa capaz de não apenas responder, mas repontar de forma exata sobre o destino do país.

Logo, constata-se uma crítica sobre a forma como o país estava sendo trilhado: de um lado, com a mão de ferro pelas Forças armadas; e, de outro, com a pregação do marxismo através de religiosos infiltrados dentro das igrejas. Diante desse primeiro parágrafo, manifesta-se, como sugestão crítico-reflexiva, a pergunta na mente do leitor: "seria o orador essa pessoa de mediana cultura e de bom senso capaz de responder exatamente Para aonde marcha o Brasil?”.

Baseando-se no parágrafo, "Se as autoridades [...] é fácil a qualquer pessoa [...] se continuar [...]", conforme nossa análise, duas afirmativas condicionais: a primeira afirmativa está condicionada à atuação da segurança nacional, citando as Forças Armadas; a segunda afirmativa está condicionada à atuação comunista representada pelo bispo de São Felix do Araguaia. Temos assim, os rumos do Brasil na dependência da atuação dessas duas oposições ideológicas e partidárias. Sob a ótica de Fernandes Barbosa, para conseguir responder com exatidão e bom senso sobre os rumos do país, era necessário, impreterivelmente, que a pessoa apta a discursar sobre essa questão fosse centrada, situada no meio, e não localizadas em oposições extremistas radicais. Isto é, que seja uma pessoa capaz e disposta a dialogar. 
Na sequência, Fernandes Barbosa (1978) introduz em seu discurso fragmentos de poemas do bispo Dom Pedro Casaldáliga, extraídos do livro Tierra Nuetra, Liberdad, construindo seus argumentos a partir da leitura crítica e análise satírica desses poemas, tentando responder a pergunta Para aonde marcha o Brasil?. Assim diz: "Para chegar à lógica conclusão, basta folhear TIERRA NUESTRA, LIBERDAD, de autoria do subversivo prelado, e ler, nas páginas 129 e 117, estes versos, de profundo amor telúrio e tocante fraternidade" (FERNANDES BARBOSA, 1978, p. I - grifos no original). No parágrafo, está explícita a contradição irônica na forma de tratamento dirigida ao bispo como "subversivo prelado" e cujos versos são de "profundo amor telúrio e tocante fraternidade".

Então, temos o duplo sentido dito por meio da ambiguidade, do double coding: a voz irônica do girondino, e a voz do jacobino que demonstrava fé em ver o comunismo se multiplicando, como esperança de amor e fraternidade, termo esse que remete à Revolução Francesa no século XVIII, como uma revolução militar para uns ou comunista para outros. Vejamos o trecho do poema do bispo citado e comentado por Fernandes Barbosa (1978):

$$
\begin{aligned}
& \text { Malditas sejam todas as cercas! } \\
& \text { Malditas todas as sociedades privadas, } \\
& \text { Que nos privam de viver e de amar! } \\
& \text { Malditas sejam todas as Leis (...) }
\end{aligned}
$$

Tenho fé de guerrilheiro

e amor de revolução (...)

(CASALDÁLIGA apud FERNANDES BARBOSA, 1978, p. II)

Em seguida, Fernandes Barbosa (1978) desenvolve um comentário ambíguo sobre a poesia do bispo, que pode ser entendida como duplo e ambíguo sentido, dando ênfase à "fé de guerrilheiro" e ao "amor de revolução", constatada na atuação engajada do poeta e líder religioso:

Depois dessa palpável e acintosa prova de posição política, de nuança ideológica, de credo partidário, de filosofia de vida, por parte do servo humilde do Senhor, e que tem o desplante de proclamar, aos quatro ventos da América, a sua 'fé de guerrilheiro' e o seu 'amor de revolução', ainda resta alguma dúvida, quanto ao destino a que almeja e pretende arrastar o país os eternos e paradoxais defensores dos direitos do homem? Creio que não! (FERNANDES BARBOSA, 1978, II - grifos no original).

Logo mais, Fernandes Barbosa (1978) encerra o parágrafo acima com uma pergunta e uma resposta que, embora não reponte precisamente para o destino do país, mas sugere, na dimensão implícita do discurso, que a marcha dos comunistas almejava alcançar o socialismo, 
através da campanha marxista pregada pelos militantes comunistas, tal como ocorreu em outros países socialistas citados na obra. O parágrafo termina com a voz satírica e irônica de Fernandes Barbosa que chama o bispo de "eternos paradoxais...", embora ele demonstrasse praticar da mesma maneira o discurso paradoxal ao dar vozes a dois "eus" opostos, mas unidos pelo desejo de revolução que parecia brotar do sonho revolucionário do poeta.

O discurso continua e nele predomina a voz do Fernandes Barbosa que confessa estar lendo e relendo as poesias do bispo comunista, como quem sugere ao leitor: "Vejam, estou lendo os poemas comunistas do bispo Dom Pedro Casaldáliga!", e despertando a atenção e curiosidade do leitor que, talvez, nem soubesse da existência de tais poemas:

Mas, se permanece uma pequena sombra de incerteza, vou abrir e manusear, mais uma vez, a obra já citada, a fim de que o leitor, tolerante e paciencioso, páginas 124, 128 e 129, possa ler e constatar com que afeto, com que carinho e, principalmente, com que elegância de tratamento, o confesso agitador comunista, poeta-bispo de São Felix do Araguaia, se refere aos proprietários rurais. A todos, sim. Não só aos que - pelo trabalho persistente e honesto de amainho da terra, ferindo os pés à ponta esfarpada das raízes - vivem hoje no seu pedaço de chão, a sonhar com o milagre da germinação das sementes e com o esplendor cantante das espigas sazonadas. Mas, também, e de maneira mais agressiva e direta, àqueles que - no lombo de um cavalo, na rudeza das tropeadas e dos pastoreios, no trabalho do dia-a-dia campesino, pele tostada ao calor da brasa de angico dos sóis de estio, e castigados pela geada e pelo látego molhado dos minuanos repontando garoas - souberam cercar várzeas ou coxilhas, tornando-se legítimos proprietários, por aquisição ou por herança, de fazendas, estâncias e granjas, que se foram desmembrando das velhas sesmarias do Rio Grande (FERNANDES BARBOSA, 1978, II e III- grifos no original).

É notório que, no meio do discurso, Fernandes Barbosa cita três páginas, mas só apresenta um fragmento do poema, ou seja, não expõe o poema completo. Tal procedimento é repetido mais de uma vez na obra. Logo, talvez interesse, em trabalhos futuros, consultar as obras do bispo, a fim de averiguar o teor poético contido nas páginas citadas. Em relação à obra poética do Bispo, nesse artigo, dedicaremos aos poemas contidos na obra Para Aonde Marcha o Brasil? (1978).

Na dimensão explícita do discurso, do parágrafo de citação, Fernandes Barbosa (1978) inicia com a conjunção coordenativa adversativa "mas", assinalando mais uma vez a adversidade no discurso ambíguo, separado por parágrafos, porém dependentes, e seguido de uma pausa marcada pela vírgula, talvez para recuperar o fôlego e trazer a voz do representante dos ruralistas, que inicia com a conjunção subordinativa condicional "se", realçando que o discurso dele está condicionado ao discurso do bispo, e chamando a atenção para a forma de 
tratamento com qual o bispo "comunista confesso" "se refere aos proprietários rurais". Notase que o orador expõe os dois tipos de proprietários rurais, alvo dos poemas do bispo: aqueles que conquistaram a terra através do trabalho árduo e os que conquistaram através de herança ou por meio da Reforma Agrária, causa essa que o Fernandes Barbosa abraçou e defendeu, conforme texto “Inicia-se o Movimento pela Reforma Agrária”, publicado em 1955, na Revista Novo Horizonte. Veja-se um trecho do discurso do Fernandes Barbosa, quando defendeu o movimento e tentou apaziguar a reação dos proprietários rurais preocupados com suas terras:

Meus amigos:

Por acreditarmos no Brasil, no espírito empreendedor de sua gente, na capacidade criadora de seu povo, no patriotismo jamais destemido dos descendentes de um Sepé, de um Guairacá, de um Vidal de Negreiros, de um Henrique Dias, de um Felipe Camarão, de uma Maria Quitéria, de um Fernão Dias, de um Borda Gato - cidades ...- é que aqui nos encontramos, de alma alvoroçada, olhos voitados para o Brasil d eamanhã, emprestando a nossa modesta colaboração aos gigantes dessa cruzada - A campanha Nacional da Reforma Agrária.

Medida que se impõe, não pode e não deve assustar aos nossos fazendeiros, que, no silêncio verde das fazendas, trabalham e produzem, ajudando a construir a grandeza da Pátria, e cuja propriedade, portanto, tem finalidade social. [...] Com que prazer, senhores, eu abracei essa causa! (sic.FERNANDES BARBOSA, 1955).

Depois de chamar a atenção para os proprietários rurais, ele lança mais um fragmento do poema do bispo de Dom Pedro Casaldáliga:

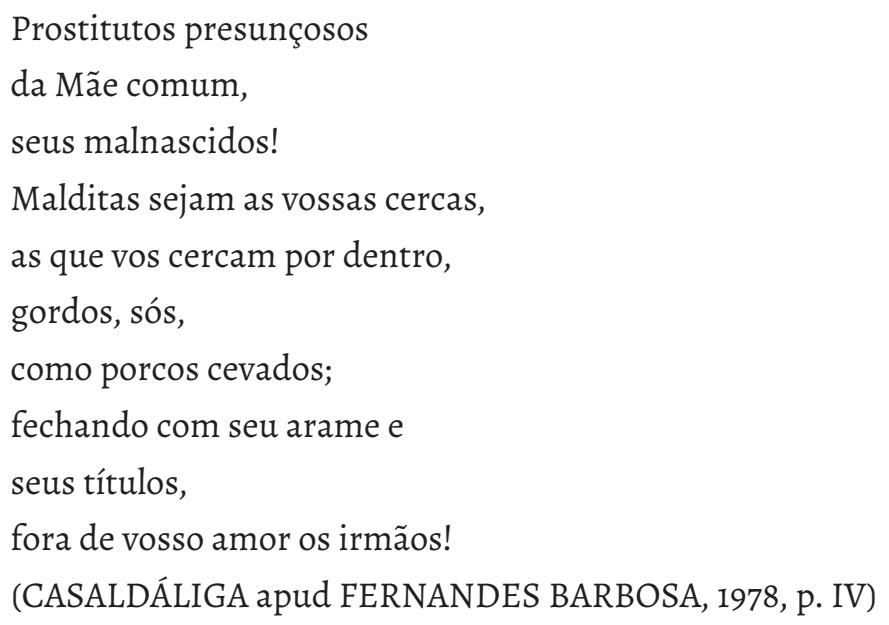

A voz do ruralista Fernandes Barbosa (1978) é direta em resposta ao poema do bispo que é considerada ofensiva aos olhos dos ruralistas: 
Mãe comum é a terra, que o maculador da batina e centurião de Herodes - e que jamais plantou uma árvore de sombra, nem falquejou um amarilho para fazer um canzil - deseja partilhar e avançar num pedaço para viver, talvez à custa de um preposto que se alojará à gleba extorquida, para trabalhar... para o bispo, porque ele nunca fez e não sabe fazer coisa alguma, a não ser, com mão de mestre, lançar a semente da discórdia à terra lavrada e discada do Senhor (FERNANDES BARBOSA, 1978, p. IV).

Observa-se que, de um lado, a voz eu lírica do bispo identificado como jacobino, e, do outro, a voz do Fernandes Barbosa que responde à linguagem extremista e ofensiva do bispo e em defesa dos ruralistas, os quais representou quando atuou como representante dos orizicultores de Cachoeira do Sul.

Em seguida, volta a citar o poema do bispo como força argumentativa do seu discurso:

Mas para viver,

eu já quero ter

a parte que me cabe

no latifúndio seu:

que a terra não é sua,

seu doutor Ninguém!

a terra é de todos

porque é de Deus!

[...] Mas para viver,

Terra eu quero ter.

Com Incra ou sem Incra,

Com Lei ou sem Lei.

(CASALDÁLIGA apud FERNANDES BARBOSA, 1978, p. IV-V)

Com esses três fragmentos de poemas do bispo Dom Pedro Casaldáliga, Fernandes Barbosa (1978) encerra os comentários satíricos acerca da obra Tierra nuetras, liberdad e passa a ler e comentar poemas comunistas de outro livro, fazendo antes uma apresentação da obra ao leitor, para que este possa consultar a obra e lê-la também, acompanhando-o. Assim ele diz: "As páginas 58 e 59, de outra publicação subversiva de D. Casaldáliga, YO CREO EM LÁ JUSTICIA Y EM LA ESPERANZA', lá está, como razão de sua vida, e um aberto convite de jacobino à derrubada do Governo e de assalto armado à riqueza” (FERNANDES BARBOSA, 1978, p. V).

Nessa apresentação, o poeta traz a definição do termo jacobino como um "subversivo" esquerdista, preocupado em tomar posse de terras por meio de lutas armadas. Se tal definição de jacobino serve para definir o perfil do bispo, talvez sirva para definir também o perfil de João do Adro. Sendo assim, acaba dando possíveis pistas da personalidade de seu pseudônimo 
jacobino João do Adro, pois ao definir a identidade do Bispo comunista como jacobino, de algum modo, deixa evidente a concepção que o autor tem sobre o termo "jacobino" associando-o à "esquerdista" e "comunista". Logo após, cita trecho do poema do bispo Dom Pedro Casaldáliga:

Incito à subversão

Contra o poder e o dinheiro.

Quero subverter a Lei

Quero perverter o povo em grei

E o Governo em carniceiro.

(Meu Pastor se fez Cordeiro,

Servidor se fez meu rei).

(CASALDÁLIGA apud FERNANDES BARBOSA, 1978, p. V)

Mais adiante, Fernandes Barbosa parece deixar escapar a voz do jacobino João do Adro, pseudônimo que usou ao longo se sua produção literária satírica de cunho político, através da voz irônica do girondino ao tecer elogios ao bispo Dom Pedro Casaldáliga, relembrando a figura do Che Guevara, referindo-se a ele com "M" maiúsculo e seguido de reticências:

O bispo é simplesmente encantador!...

Tem o condão de prender e de arrebatar as criaturas, as pessoas sensíveis às manifestações líricas da alma, através de poema como este, de evocação e de saudade, quase uma elegia ao saudoso e querido Che Guevara, morto em escaramuças guerrilhescas na Bolívia, mas cada vez mais redivivo no coração e na lembrança do servo camarada que, sempre submisso, revela não haver renegado o Mestre... da guerrilha urbana (FERNANDES BARBOSA, 1978, p.V e VI).

No fragmento acima, Fernandes Barbosa (1978), partindo da argumentação, conceitua o bispo Dom Pedro Casaldáliga de feição elogiosa, embora desconfie da ironia, como "encantador". Isso ocorre após a leitura e comparação dos poemas do bispo Dom Pedro Casaldáliga, cujos três primeiros citados revelam o extremismo crítico e satírico à sociedade privada e ao capitalismo burguês. Já esse último, apesar de também incitar à subversão, o eu-lírico no poema do bispo é menos extremista e mais respeitoso, no que diz respeito à forma de tratamento aos ruralistas, além dos poemas evidenciarem um empenho maior na labuta com a linguagem literária, notória por meio da identificação de intertextos bíblicos, literários, políticos e históricos. Ou seja, mediante à mudança discursiva de comportamento do bispo, ocorre a modificação discursiva na voz de Fernandes Barbosa, pois, conforme vimos, quando o bispo ameniza sua voz extremista, Fernandes Barbosa o chama de "encantador". Demonstrando que sua atuação discursiva está condicionada ao outro. 
Ao que parece, o elogio é atribuído por causa do referente bíblico identificado nos dois últimos versos do fragmento poético citado acima, logo a expressão é de um poeta e cristão assumido ${ }^{5}$. Além disso, pela identificação com a figura de Che Guevara referenciado no poema, é possível que haja leitura alegórica do militante esquerdista com "Cristo". Na sequência, Fernandes Barbosa volta a citar a pela última vez a poesia do bispo, mais uma vez mencionando Che Guevara, agora como um elo de união entre o eu-lírico e leitor:

Lembrarão que sou um padre "novo".

Pouco me importa!

Somos amigos

E falo contigo agora

Através da morte que nos une,

Estendendo-te um ramo de esperança,

Todo um bosque florido

De perenes jacarandás íbero-americanos,

Querido Che Guevara!

(CASALDÁLIGA apud FERNANDES BARBOSA, 1978, p. VI)

Encontra-se no poema do bispo Dom Pedro Casaldáliga a referência explícita às flores "Jacarandás", que remete por alusão ao título de Minhas flores de Jacarandá (1944), de Fernandes Barbosa, segundo livro do poeta gaúcho, possivelmente avisando o leitor de um diálogo intertextual por referenciação explícita entre os dois poetas. Em seguida, ele diz: "Em face disso, depois disso, será que estarei acusando gratuitamente, falsamente, levianamente, um fervoroso e inatacável democrata-cristão? Não! Absolutamente, não!" (FERNANDES BARBOSA, 1978, p. VI). De fato, como ele disse, o bispo foi um comunista assumido e não um democrata-cristão. Com a indagação e afirmação, o poeta estabelece um antagonismo entre o bispo jacobino e seu eu girondino, e assim marcando posições de seus "eus"-líricos antagônicos, sob a ótica de João do Adro, mas iguais sob a ótica de Fernandes Barbosa.

Em seguida, Fernandes Barbosa apoia sua argumentação, baseando-se no que ele chama de "provas concretas, documentos insofismáveis, em atestados irretorquíveis, em testemunhos insuspeitos, com substanciados em obras literárias publicadas, e em atos praticados por Dom Pedro Casaldáliga..." (FERNANDES BARBOSA, 1978, p. VI).

No entanto, ele apenas faz referências a esses documentos ou arquivos que servem como exemplos em sua argumentação, mas não os apresenta e nem apresenta maiores detalhes sobre o material citado e, até o momento, desconhecido. Após essa exposição de argumentos, Fernandes Barbosa (1978) inicia o discurso com uma conjunção subordinativa condicional,

${ }^{5}$ Ver poema "Sou Cristão", em Antologia organizada pela família do poeta e disponível nos arquivos do Museu Municipal de Cachoeira do Sul-RS. 
revelando-se condicionado à atuação dos integrantes da CNBB - Conferência Nacional dos Bispos do Brasil-que até o momento não havia feito nada para punir o bispo, dando a entender que nada seria feito e que ele de maneira semelhante nada faria.

Diante da incapacidade de agir, resta-lhe o discurso ou a linguagem como forma de militância e combate. É através dela que Fernandes Barbosa propõe sua intervenção sugerida na dimensão explícita do discurso, iniciando a proposta em latim, e evidenciando que está adotando a mesma linguagem satírica e irônica que o bispo empregou em seus poemas. Vejamos a citação abaixo:

Persona non grata, que já deveria ter recebido passaporte para que fosse, livremente, falar em assalto ao Poder e pregar os direitos do homem sem medo dos paredões, das prisões siberianas, das célebres lavagens cerebrais - na Rússia, na China, em Cuba, na Coréia, no Vietnã, na Argélia, na Polônia, ou na Alemanha Oriental (FERNANDES BARBOSA, 1978, VIII).

Percebe-se, na citação acima, uma enumeração dos países socialistas listados como opção ao bispo para que ele seguisse livremente pregar o marxismo, que Fernandes Barbosa (1978) define de forma paradoxal como "assalto ao Poder" e "direitos do homem". Ou seja, o primeiro conceito retrata a visão dos democratas, da extrema direita, já o segundo retrata a visão dos comunistas, da extrema esquerda.

Em seguida, Fernandes Barbosa (1978) finaliza o os argumentos pondo em evidência sua percepção dos fatos, por meio da manifestação de seu sentimento e de seu pensamento, engendrando uma síntese crítica dos argumentos expostos:

Na minha maneira de sentir e de pensar, e de sempre externar o que sinto e penso, sem me preocupar com suscetibilidades, lavro o meu protesto e escrevo meu libelo contra esse estado de coisas, vibrando, em cada rua da minha cidade pacata, esta clarinada de alerta, que espero ressoe e continue a ressoar à concha auditiva das autoridades, como a eterna voz do mar no ventre nacarado dos búzios (FERNANDES BARBOSA, 1978, VIII).

No desenrolar discursivo, apresenta uma nota explicativa informando exatamente para onde o leitor deve marchar para encontrar os poemas do bispo Dom Pedro Casaldáliga, apresentando detalhadamente a fonte e divulgando aos leitores interessados a poesia do bispo São Felix do Araguaia, bem como onde a encontrar. Talvez fosse interessante um trabalho que tivesse como objetivo estudar e analisar os poemas do bispo Dom Pedro Casaldáliga citados pelo poeta Fernandes Barbosa, a fim de compreender melhor seus aspectos literários, históricos, político e cultural, e, quem sabe, perceber algum diálogo, aproximando e distanciando, 
entre os dois bispos e Fernandes Barbosa, e a relação com outros poetas e escritores do período ditatorial. Abaixo, a localização dada por Fernandes Barbosa, que compartilho:

Figura 2 - Nota autografada de Para aonde marcha o Brasil? (1978).

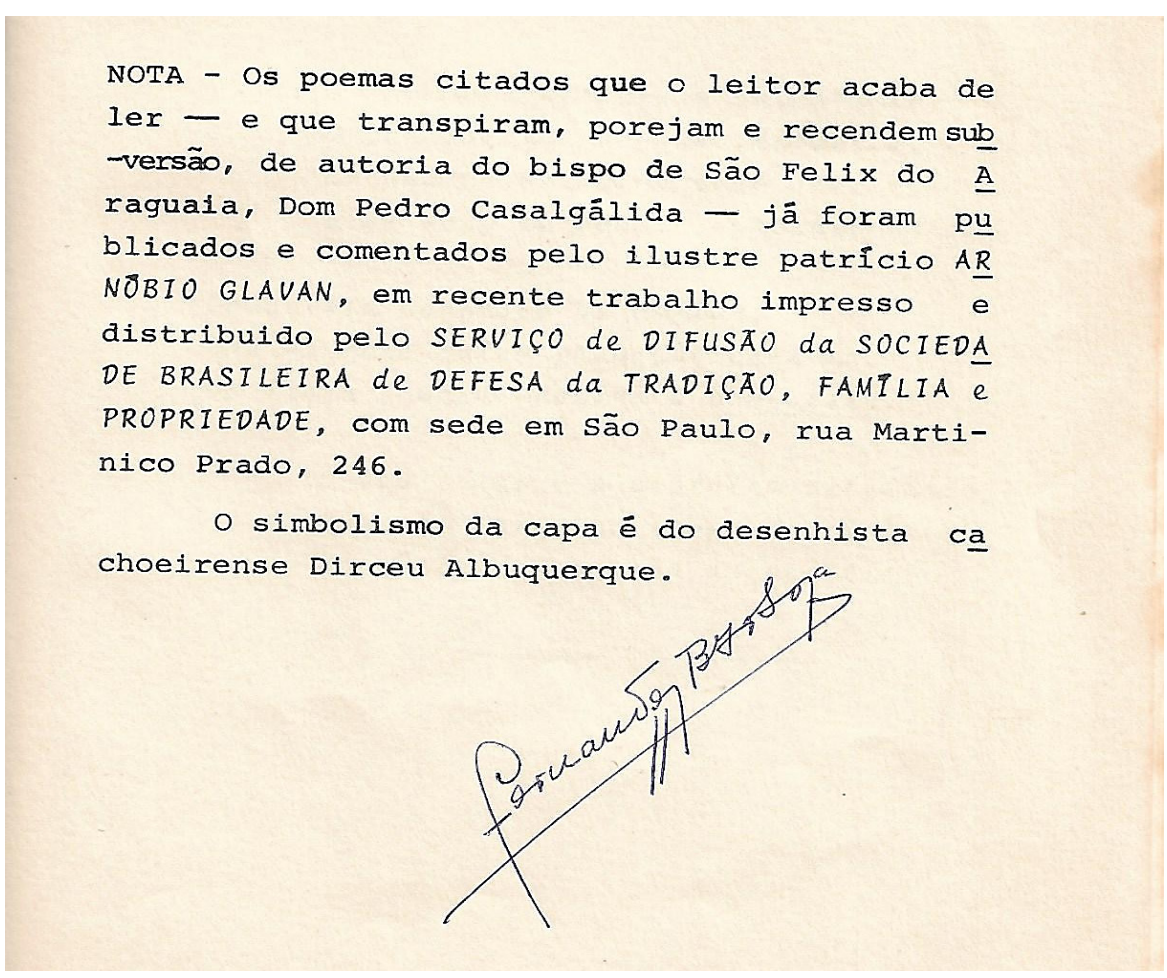

Fonte: Original do autor Fernandes Barbosa (1978).

Após o exórdio e a argumentação de seu discurso, ou sermão ao bispo Dom Pedro Casaldáliga, Fernandes Barbosa apresenta três poemas de sua autoria que funcionam como uma peroração dividida em três partes em forma de poemas-respostas: "Perfil de um bispo", "Pelo mesmo caminho..." e "Parei contigo", que analisaremos mais adiante. Com tais poemas, fica evidente a intenção de Fernandes Barbosa: convencer os leitores e apresentar suas virtudes criativas engenhadas em forma de lírica e empenhadas na recapitulação do que já foi discursado anteriormente pelo orador, a fim de convencer, por meio da sensibilidade lírica de manifestações da alma, e, por fim, induzir os leitores a se engajarem em sua marcha e militância, em busca de respostas sobre Para aonde marcha o Brasil? (1978).

\section{PeroraÇão: IDENTIDAde, MARCha e RUPtURA EM tRêS POEMAS - RESPOSTAS}

Em Perfil de um bispo, o bispo Dom Pedro Casaldáliga é traçado por Fernandes Barbosa (1978) em forma de caricatura, a partir da visão ambígua e da interpretação subjetiva do 
eu-lírico, que revela e realça os exageros idealizados nas leituras de poemas por meio dos quais idealiza a figura do bispo. Logo, a motivação lírica que entusiasmou Fernandes Barbosa fluiu de sua recepção crítica dos poemas do bispo e seu ataque à sociedade privada e aos ruralistas.

Consequentemente, o poema é antes uma resposta direta e criativa de um leitor intelectual, também poeta conhecedor de todos os esquemas formais e estilísticos cabíveis ao ato de criação literária. No exercício da criação lírica, percebe-se a noção de mimese por emulação poética, que geralmente ocorre quando um poeta ou escritor emula outro em busca de superação e reconhecimento, ou seja, mimese no sentido de emulação, corresponde não apenas ao ato de imitar, mas imitar para tentar superar algo daquilo que se é imitado (OLIVEIRA, 2016, p. 40). Nesse campo de labuta intelectual e artística, o poema resulta em uma emulação dos poemas do bispo Dom Pedro Casaldáliga, em busca de superação e reconhecimento. Observase, abaixo, o poema caricatural Perfil de um bispo, traçado por Fernandes Barbosa:

Na luta do fuzil e do rosário,

O bispo de Araguaia mais se alteia,

Pois usando jargões de panfletário,

O coração das massas incendeia.

E ninguém contradiz o salafrário,

O Che Guevara que não titubeia,

Em chamar de suíno quem semeia,

E se fez, na labuta, proprietário.

Comunista confesso de batina,

Que na mais falsa pregação cretina,

De lança investe contra a burguesia.

O seu trigo é doutrina deletéria,

Que ele lança no campo da miséria,

No cálix da sagrada eucaristia!

(FERNANDES BARBOSA, 1978, p. X)

Em comparação com os poemas do bispo de São Felix do Araguaia, o primeiro aspecto que suscita à análise é a forma estrutural em que ambos se apresentam. Apesar dos poemas do bispo serem citados apenas por fragmentos, e não os poemas inteiros, nota-se que seus são apresentados em forma estíquicas ou livres e, tal como explica Massaud Moisés (1995, p. 211)), isso ocorre quando "as estrofes se montam de forma irregular ou arbitrária". Ou seja, os poemas do bispo são arbitrários porque querem impor sua própria forma ou sua própria estrutura, a partir da demolição das estruturas tradicionais conhecidas como formas fixas. 
Já o poema de Fernandes Barbosa (1978) mantém a forma fixa do soneto italiano em decassílabos heroicos, com rimas perfeitas disposta no esquema ABAB ABBA CCD DDD, esquema métrico que ele adota em outros dois poemas do protesto ou libelo Para aonde marcha 0 Brasil? (1978). Tanto o bispo São Felix do Araguaia quanto Fernandes Barbosa (1978) cultivam a linguagem satírica que alude ao estilo gregoriano, principalmente os poemas líricos satíricos usados como setas inflamadas contra o Estado e a Igreja.

No primeiro verso que inicia o poema de Fernandes Barbosa (1978), "Na luta do fuzil e do rosário", nota-se a síntese do paradoxo que será cultivado ao longo do poema, esboçando a ideia paradoxal no fato de um líder religioso praticar uma militância que, sob a ótica do eu-lírico girondino, incita à subversão e à violência, uma vez que o bispo se apoia em armas como "fuzil" - instrumento de guerra civil militar - e "rosário" - instrumento de uso religioso pelos cristãos católicos, fazendo dessa militância ideológica da extrema esquerda como algo sublime, glorioso e, até, religioso. Além disso, quando o eu-lírico traz à tona a "contradição", põe em evidência não apenas o teor do poema do bispo, por recapitulação, mas também o próprio fazer poético, exercendo assim a metalinguagem.

Uma provocação satírica e irônica que o eu-lírico explora, na segunda estrofe, reside no fato de ninguém contradizer o "salafrário", deixando implícita a intenção de revelar a contradição na atuação política-religiosa do líder religioso e militante engajado na causa marxista. Prontamente o eu-lírico diz "O Che Guevara que não titubeia”, ou seja, não hesita, não vacila, não cambaleia em sua luta. Parece óbvio e irônico que o eu-lírico não se refere à figura do revolucionário marxista Che Guevara (1928-1967), morto há 11 anos, contando regressivamente a partir de 1978, mas o cita estabelecendo uma relação metonímica bispo/ representante ideológico. Em síntese, percebe-se o bispo Dom Pedro Casaldáliga assumindo a identidade e militância de "Che" em seu engajamento marxista.

Em suma, o poema é construído em torno desse paradoxo entre o discurso de militância política e o discurso religioso. Nos poemas de Fernandes Barbosa, sente-se um espírito paradoxal que manifesta um ideal que milita e marcha em busca de união e propõe o abandono dos "fuzis" e a fraternidade.

O paradoxo é arquitetado em torno do double coding e da ironia intertextual, através de referentes identificáveis na camada explícita e implícita na matéria poética. Nela, percebem-se espiritualmente os intertextos bíblicos, por meio da identificação dos referentes "suíno (porco)", "trigo" e "semeia". O primeiro pode ser interpretado em uma relação intertextual metonímica "suíno/porco" que na Bíblia da tradição judaico-cristã simboliza, assim como o cão, um animal imundo, a exemplo de quando é relatado o momento em que Jesus expulsou demônios de um homem, da província dos gadarenos, com espíritos imundos e esses espíritos rogaram para habitar uma manada de porcos (BÍBLIA, 2017, MARCOS 5.1-20, p. 1242).

Analisando por esse sentido, o bispo ao atacar os proprietários rurais, chamando-os de suíno/porcos, deixa subentendido que os ruralistas tinham espírito imundo. Na percepção do 
eu-lírico, o bispo demoniza a sociedade privada e os proprietários rurais, quando os chamou de "prostitutos presunçosos / malnascidos / de mãe comum" e de "porcos", conforme vimos nos poemas analisados. Dessa forma, baseando-se na análise comparada com os intertextos bíblicos, observa-se que ocorreu a demonização do outro na construção subjetiva das identidades.

Ainda sobre o referente suíno/porco, identificamos outro intertexto bíblico quando Jesus, ao advertir sobre o juízo temerário, diz "nem deitei aos porcos as vossas pérolas" (BÍBLIA, 2017, MATEUS, 7.6, p.1190), significa dizer que não é aconselhável desperdiçar palavras com quem não as apreciam, ou não as entendem. E, mais adiante, quando o eu-lírico diz "em chamar de suíno quem semeia", o referente semeia/semear também nos remete à "Parábola do semeador" em que Jesus fala por parábolas a uma multidão e, em síntese, prega que, para a semente dar bons frutos, ela está condicionada a cair em uma terra boa e fértil (BÍBLIA, 2017, MATEUS, 3.1-23, p. 1200). Sendo assim, o eu-lírico faz referência, de forma implícita, a si mesmo como a terra onde a palavra do bispo Dom Pedro Casaldáliga foi plantada e germinou em frutos líricos, através do cultivo da criatividade e do pensamento intelectual.

O segundo referente identificado do texto bíblico é o "trigo" que na Bíblia simboliza prosperidade e fartura, e nos remete por associação à parábola do joio, quando Jesus adverte que deve haver separação entre o joio e o trigo, pois o joio estraga o trigo (BÍBLIA, 2017, MATEUS 3.24-43, p.1200-1201). No poema, o trigo é citado com valor de subversão, pois o "trigo é doutrina deletéria", ou seja, é um trigo venenoso, danoso, nocivo, mas próximo do joio. Nessa intertextualidade, percebe-se a ambiguidade na interpretação subjetiva do símbolo, ou seja, o que pode ser danoso, venenoso ou nocivo para uns pode simbolizar fé e esperança de prosperidade para outros, dependendo do horizonte de expectativa do leitor.

A intertextualidade religiosa é percebida através da identificação dos referentes da tradição religiosa cristã católica, são eles "rosário", "batina", "confesso (confessar)", "doutrina", "pregação", "cálix da sagrada eucaristia" e "bispo". Com relação à intertextualidade com a História do século XX, ela ocorre por meio da identificação de intertextos da militância histórica-política, que são os "jargões de panfletários", "massas" e "Che Guevara". Esses referentes são empregados com valor de subversão, pois há um empenho criativo na reelaboração dos significados por meio do uso de figuras de linguagem que multiplicam significativamente os sentidos dos referentes. Assim como na linguagem do Bispo comunista, por exemplo, Che Guevara não representou apenas um líder político, mas passa a ter a sua identidade associada a Jesus Cristo do cristianismo, numa perspectiva histórica, valorizando mais questões materiais.

Observa-se que as identidades do eu-lírico e do bispo são construídas de forma relacional, ou seja, a partir de sua relação com o outro(s). Isso nos lembra do pensamento de Homi Bhabha (1994), que aborda questões contemporâneas pertinentes sobre temas que envolvem identidade, hibridismo e pós-colonialismo. Em relação à construção da identidade, Souza (2011), interpretando Bhabha (1994), explica que: 
nesse processo relacional da construção da identidade, o retorno de uma imagem marcada pelo traço da duplicidade, do lugar do Outro, surge o ar de uma 'certa incerteza' que envolve o corpo do sujeito, ao mesmo tempo atestando sua existência (alocando-lhe uma identidade) e ameaçando desmembrá-lo (construindo essa identidade parcial e dialógica em função de um Outro). Assim, em termos psíquicos, o hibridismo no bojo da identidade leva ao fato de que a identidade 'nunca existe a priori, nunca é um produto acabado; sempre é apenas o processo problemático de acesso de uma imagem de totalidade' (BHABHA, 1994 apud SOUZA, 2011, p. 122).

Seguindo essa linha de raciocínio, a identidade do bispo e do eu-lírico no poema de Fernandes Barbosa são construídas através da imaginação do eu e do outro, imaginação cultivada através da leitura de um corpus poético que versa sobre uma temática específica, a militância política do comunismo. Isto é, a identidade é construída a partir de uma imaginação poética guiada por esse horizonte.

Octávio Paz (1982) explica que a imaginação poética não é uma invenção, mas uma descoberta da presença, no sentido de descobrir a imagem no mundo no qual se emerge como fragmento e dispersão, percebendo no uno o outro, desenvolvendo na linguagem a sua virtude metafórica ao dar presença aos outros. A poesia é, então, a procura dos outros, e descoberta de outridade (PAZ, 1982, p. 319). Assim, a construção da identidade é também uma construção de uma entidade de poder. Quanto a isso, vejamos agora o caminho que o eu-lírico de Fernandes Barbosa imagina que o Brasil seguiu, marchando no século XX, por meio da leitura de "Pelo mesmo caminho...":

Pela batina Salvador Allende,

Ao Governo do Chile ele ascendeu,

E agora, em nossa casa, se pretende,

Escrever o que lá já se escreveu.

Por aqui muito padre ensandeceu,

Cada prelado, que por bispo atende,

Transformou cada igreja em Ateneu,

Onde o marxismo, sem querer, se aprende.

Os surrados slogans da caterva,

Vindos da Rússia, em latas de conserva,

É o vinho espiritual que se consome. 
Enquanto a subversão, escrita em faixas,

$\mathrm{Na}$ linguagem comuna das mais baixas,

É o panis angelorum que se consome!

(FERNANDES BARBOSA, 1978, p. XI)

Em relação à metrificação, o poema se apresenta na estrutura de soneto italiano em decassílabos heroicos, com uma incidência no último verso em que temos um hendecassílabo, também conhecido como arte maior, com rimas perfeitas disposta no esquema $\mathrm{ABAB} B A B A$ CCD EED. Já no que diz respeito à matéria lírica, temos um conteúdo histórico e cultural utilizado como crítica satírica, irônica e marxista, engendrada pela absorção dos significados dos referentes que se fundem na tessitura poética, criando múltiplos sentidos sem romper drasticamente com os sentidos originais, mas conciliá-los.

No campo intelectual e espiritual, o eu-lírico milita na tentativa de responder, de modo a conciliar os contrastes, por meio da sátira e ironia, à pergunta de seu protesto e libelo Para aonde marcha o Brasil? (1978). Sob a ótica do eu-lírico, de Fernandes Barbosa, o Brasil, caso continue marchando pelo mesmo caminho apontado pelo bispo comunista, continuará seguindo "Pelo mesmo caminho..." dos países socialistas, como o Chile e Rússia, referenciados no corpo do poema por recapitulação aos argumentos discursivos apresentados anteriormente.

No poema "Pelo mesmo caminho...", predomina o intertexto histórico, associado à atuação e a disseminação do comunismo - através da identificação dos referentes "Salvador Allende”, "Governo do Chile”, "marxismo", "slogans”, "Rússia”, "subversão”, "faixas” - e intertexto cultural da religião cristã do catolicismo - "batina”, "igreja”, "linguagem comuna”, "panis angelorum". O eu-lírico explora os referentes de modo a denunciar o marxismo sendo pregado em âmbito nacional e internacional, construindo o poema em torno desse diálogo internacional entre Brasil / Chile e Brasil / Rússia, em um movimento de fora para dentro e de dentro para fora, a fim de mostrar a importação e exportação ideológica do marxismo dentro e fora das igrejas. Em síntese, o eu-lírico denuncia e põe em evidência o marxismo, ensinado e assimilado no interior das igrejas e deslocando-se para as ruas.

Nos versos da última estrofe, é evidente a ambiguidade em relação ao tipo de linguagem que o bispo utiliza e que o eu-lírico menciona como "comuna", em duplo sentido: o religioso fazendo referência à origem do português brasileiro, ou seja, à língua românica e sua evolução para a língua latina, usada por líderes religiosos do catolicismo; e comuna como uma derivação regressiva de "comunismo". Nesse contexto, "comuna" também faz referência a comunne, que é explicado por Engels, em suas anotações no Manifesto Comunista, como um termo "usado na França, pelas cidades antes mesmo de terem conquistados de seus senhores feudais o autogoverno e direitos políticos como o Terceiro Estado" (ENGELS, 1890 apud MARX; ENGELS, 1998, p. 64). 
Ainda em relação à linguagem, avista-se outra ambiguidade na adjetivação "baixa" erguendo duplos sentidos: o de submissão a uma linguagem estereotipada como "alta", que está acima e, portanto, a linguagem baixa representa o estereótipo da linguagem do povo, da cultura de massa, ou daqueles que ocupam a infraestrutura do Estado. Assiste-se, no poema, a encenação ideológica de crítica ao marxismo, como forma de representação e repressão, em que se testemunha a voz do girondino, ocupando o espaço literário e sobressaindo-se na militância intelectual, com a habilidade discursiva e no empenho com a linguagem que se impõe, justamente por suas virtudes cultivadas; e a voz do jacobino João do Adro está abaixo na camada textual, na superfície implícita do discurso do outro que se sobressai, a voz do outro, embora presente, e praticamente sufocada, despercebida na voz do eu-lírico que detém o poder da assinatura textual.

Sob a ótica girondina do democrata cristão, a obra registra a denúncia da pregação do marxismo dentro da igreja como algo que corrompe a identidade cristã e a identidade de Cristo, pois na voz hiperbólica "cada” igreja, no sentido generalizado, é transformada em Ateneu, escola onde se aprendia o marxismo, fazendo referência à escola francesa marxista. Ou seja, os cristãos católicos, ao buscarem Cristo e os ensinamentos bíblicos, encontravam nas igrejas Marx e os slogans marxistas, e, ao invés de receberem o Espírito Santo, saíam das igrejas com espírito de rebeldia, de subversão. Nota-se, portanto, uma intertextualidade histórica e cultural com valor de subversão e com críticas ao marxismo pregado do interior das igrejas.

Há outro intertexto bíblico identificável no referente "vinho espiritual", que no sentido bíblico e espiritual nos remete ao primeiro milagre de Jesus Cristo, quando, em um casamento, transformou água em vinho. No sentido religioso, "vinho" significa o sangue de Jesus Cristo e também alude à última ceia que antecedeu a traição de Judas Iscariotes ao Mestre, ao entregar-lhe aos conspiradores, momentos após Jesus haver compartilhando, com seus discípulos, o pão e o cálice que simbolizam seu corpo e seu sangue (BÍBLIA, 2017, LUCAS 22. 14-23, p.1324). Ou seja, no sentido simbólico espiritual, os intertextos bíblicos no poema representam simbolicamente as alianças que os comunistas pretendiam estabelecer com outros países socialistas citados, como Chile e Rússia. Assim, temos uma intertextualidade com valor de subversão.

Quando o eu-lírico afirma que o bispo "transformou cada igreja em Ateneu”, verifica-se uma intertextualidade literária a partir da identificação do referente "Ateneu" que nos remete, de modo mais abrangente, no contexto da Antiguidade grega, à escola onde se ensinava determinada doutrina. Um exemplo disso, e que dialoga com o poema - que compara a igreja a uma escola onde se ensinava e aprendia o marxismo - é O Ateneu (1950), romance impressionista do escritor brasileiro Raul Pompéia (1863-1895), que consagrou a estética Realista no Brasil e cujo autor manifesta sua crítica social aos princípios aristocratas da sociedade brasileira do século XX. Entre o romance e o poema, o referente "Ateneu" é usado de modo ambíguo e com valor de subversão, pois os comunistas tomam o marxismo justamente para combater certos princípios dominantes nas estruturas sociais, mas, sob a ótica do eu-lírico girondino, 
sua lógica segue a ideia de que o marxismo ensinado nas igrejas corrompe o cristianismo, por ser considerado materialista e ateu.

O último poema "Parei contigo" parece decisivo na marcha brasileira, pois encena uma ideia de ruptura, um movimento de parada com quem trata por "meu vigário" que dá sermão, na voz irônica do eu-lírico que também responde com sermão. Veja-se o poema citado abaixo:

Eu já parei contigo, meu vigário,

Não quero mais saber do ter sermão,

E digo a Cristo, às contas do rosário,

Que o seu ministro eu já larguei de mão.

Tu sempre foste um grande reacionário,

Que tem vivido só de exploração,

Em dois mil anos nunca um operário,

Provara do teu vinho e do teu pão.

Agora, te arvoraste em Robin Hood,

E queres que o país derrube e mude,

O que o próprio Evangelho edificara.

E nas lutas de rua ora te avisto,

Dando beijos de Judas no teu Cristo,

Apoiado no rifle de Guevara!

(FERNANDES BARBOSA, 1978, p.XIII - grifo meu)

O eu-lírico inicia com uma expressão pleonástica redundante em "eu já parei", marcando a dupla identificação do "eu-lírico" no verso: a primeira, de forma explícita, marcando a presença do eu-lírico girondino, à frente do verso, da linguagem; e a segunda, de forma implícita, marcando a presença do eu-lírico jacobino. Ambos mediados pelo advérbio de tempo "já", revelando o momento em que rompiam conjuntamente o diálogo com o bispo Dom Pedro Casaldáliga. Tal atitude revela o sentimento de ofendido da parte de ambos os "eu-líricos" e nos remete ao poema Solidariedade, assinado por João do Adro em manuscrito da agenda pessoal do poeta, datado de 1968, que apresento abaixo: 
Figura 3 - Poema Solidariedade manuscrito e assinado por João do Adro.

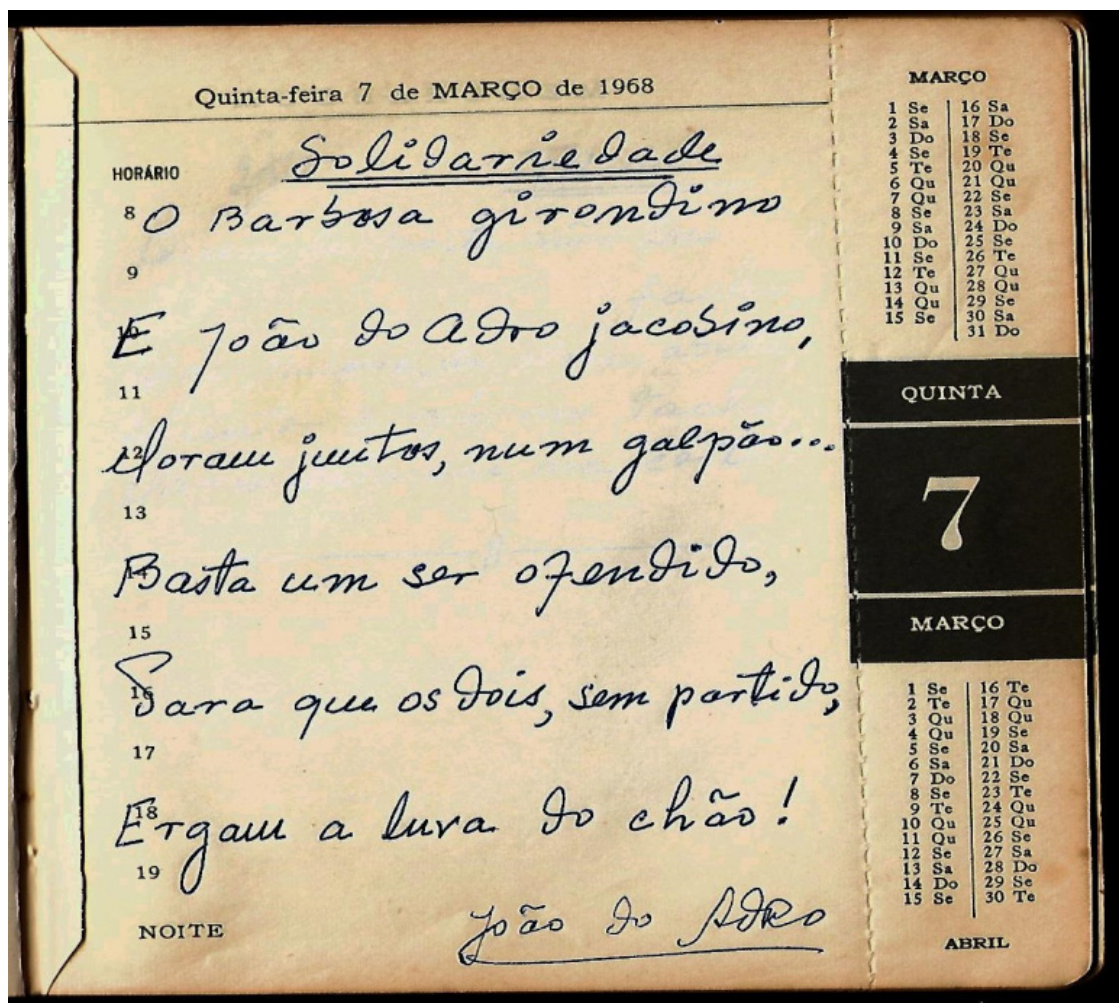

Fonte: Agenda pessoal de Nilo Fernandes Barbosa (1910-1988), original do autor.

Na visão ou no sonho ideológico do jacobino, ambos os eu-líricos "moram juntos", no sentido de compartilharem o mesmo espaço literário que o João do Adro chama de "galpão". Nesse sentido, entende-se o espaço literário tal como Foucault, ou seja, "o espaço é fundamental em qualquer forma de vida comunitária" e "fundamental em qualquer exercício de poder" (FOUCAULT apud BRANDÃO, 2013, p. 21).

Voltando ao primeiro verso do soneto "Parei contigo", o eu-lírico trata o bispo jacobino por "meu vigário", confidenciando ao leitor que a identidade que ele cria do bispo parte de uma elaboração subjetiva sua, ou seja, é a imagem identidária criada a partir da recepção dos poemas do bispo e outros textos já mencionados. Nessa confidência, a identidade do bispo é construída em torno de hipérboles, criadas a partir de referentes destacados no corpo do poema. Essas hipérboles atingem o máximo de exagero no terceiro e quarto versos, quando a identidade do bispo é associada por metáfora a Jesus Cristo a fim de criar múltiplos sentidos através da metonímica tomando bispo/Jesus/Igreja e deixar registrado a sua ruptura com a igreja, sob a justificativa apresentada na última estrofe do poema quando, por uma associação metonímica, tomando Cristo/Cristãos/Cristianismo, acusa o bispo de trair Cristo e, dessa vez, comparando o bispo a Judas Iscariotes, o traidor de Cristo. 
Mantendo diálogos intertextuais iniciados nos poemas Perfil de um bispo... e Pelo mesmo caminho, já citados e analisados. Os intertextos bíblicos são identificados através dos referentes da tradição judaico-cristã “Cristo”, "vinho”, "pão”, "Evangelho”, "Judas”, configurando-se uma intertextualidade com valor de subversão. Além desses, é possível identificar intertextos culturais religiosos do cristianismo de tradição católica - "vigário", "sermões", "contas do rosário" -e intertextos históricos de militância política de orientação ideológica de esquerda - "ministro", "reacionário", "operário", "lutas de rua”, "rifle de Guevara”.

Se, no segundo parágrafo de "Parei contigo", o eu-lírico exaltou o bispo comparando-o a Cristo, agora ele o rebaixa no sentido moral, comparando-o a Judas. Em síntese, o eu-lírico registra sua ruptura com a igreja, mas mantém o desejo de se relacionar com Cristo. Nota-se o jogo discursivo, ambíguo e paradoxal, com uso da linguagem metonímica e alegórica. Por meio da metáfora, o eu-lírico cria uma identidade paradoxal em relação ao bispo, ou seja, de herói e anti-herói, revelando de um lado o caráter subjetivo da identidade do líder religioso e, por outro lado, o sentimento do eu-lírico de se sentir traído pelo bispo. Com essa ruptura registrada em "Parei contigo", o eu-lírico finaliza seu protesto e seu libelo.

\section{Considerações FinaIS}

Em Para aonde marcha o Brasil? (1978), a marcha é guiada pela linguagem satírica de Fernandes Barbosa que, por sua vez, é condicionada à linguagem satírica do bispo Dom Pedro Casaldáliga, pois o fato da obra ser gerada como resposta e resistência, ela estabelece uma relação de dependência, carecendo de ser lida lado a lado, pois sua interpretação mais fiel ao contexto político, ideológico e cultural depende das obras as quais responde. É nessa relação de dependência que dá origem à manifestação da linguagem satírica de Fernandes Barbosa, gerada do incômodo daquele que se sente ofendido, oprimido e responde se impondo de forma condicional às obras as quais emula, sem se anular enquanto sujeito engajado na Literatura política de seu tempo, mesmo que essa imposição seja condicionada às circunstâncias políticas, históricas e culturais.

Diante das críticas, situações humano-existenciais impostas ao homem intelectual e escritor do século XX, em especial no período da ditadura civil - militar (1964-1978), Nilo Fernandes Barbosa (1910-1988) não se intimida e não recua em sua militância, na qual marcha de mãos dadas com o eu e com o outro. Marchando nesse sentido, Para aonde marcha o Brasil? (1978) é um exemplo dessa ambígua, paradoxal, mas, sob a ótica do poeta, uma necessária marcha solidária.

Você marcha, José!

José, para onde?

(DRUMMOND, 2007) 


\section{REFERÊNCIAS}

\section{Referência literária}

ANDRADE, C. D. E agora José?. In: TELLES, G. M.; SANTIAGO, S. (Org.). Poesia Completa. 1. ed. Rio de Janeiro: Nova Fronteira, 2007.

BÍBLIA SAGRADA. Tradução de João Ferreira de Almeida. Edição corrigida e revisada, fiel ao texto original. Anotações de fé de Edir Macedo. Editora Horebe: São Paulo, 2017.

FERNANDES BARBOSA, N. Solidariedade. Original do autor. Arquivo pessoal. Doação de Ana Maria Fernandes Barbosa Carlin. Poema manuscrito da agenda pessoal do poeta, assinado pelo pseudônimo João do Adro, 1968.

FERNANDES BARBOSA, N. Para aonde marcha o Brasil? 1. ed. Original do autor. Rio Grande do Sul: Gráfica Jacuí LTDA, 1978.

\section{Referências de arquivos - documentos}

SAVI, N. Fernandes Barbosa. In: Arquivo Poeta Nilo Fernandes Barbosa (reserva única). Álbum de fotografias. Doação de Ana Rita Fernandes Barbosa de Carvalho em 1999. Museu Municipal de Cachoeira do Sul-RS, 2002.

\section{Referência crítica - teórica}

BHABHA, H. K. O local da cultura. Tradução: Myriam Ávila; Eliana Lourenço de Lima Reis; Glaucia Renate Gonçalves. Belo Horizonte: Ed. UFMG, 2007.

BRANDÃO, L. A. Teorias do espaço literário. São Paulo: Perspectiva, 2013.

BARTHES, R. Aula: Aula inaugural da cadeira de semiologia literária do Colégio de França, pronunciada no dia 07 de janeiro de 1977. 1. ed. Tradução e posfácio: Leyla Perrone-Moisés. São Paulo: Cultrix, 2013.

FOUCAULT, M. A Ordem do discurso. Tradução: Laura Fraga de Almeida Sampaio. 3. ed. São Paulo: Edições Loyola, 1996.

KOCH, I. G. V.; BENTES, A. C.; CAVALCANTI, M. M. Intertextualidades: diálogos possíveis. São Paulo: Cortez, 2007.

KRISTEVA, J. Introdução à Semanálise. São Paulo: Perspectiva, 1974.

MARX, K.; FRIEDRICH, E. O manifesto comunista. Tradução: Maria Lucia Como. Rio de Janeiro: Paz e Terra, 1998. 
MARX, K.; FRIEDRICH, E. O manifesto do Partido Comunista. 1. ed. São Paulo: Expressão Popular, 2008.

OLIVEIRA, E. S. O herói Sepé em duas versões: O Uruguai e Sepé - o morubixaba rebelde. 2016. Dissertação (Mestrado em Letras) - Universidade Federal de Sergipe, São Cristóvão, 2016.

PAZ, O. O arco e a lira. Tradução: Olga Savary. Rio de Janeiro: Nova Fronteira, 1982.

SOUZA, L. M. T. M. Hibridismo e tradução cultural em Bhabha. In: JÚNIOR, B. A. Margens da Cultura - Mestiçagem, Hibridismo e outras misturas. São Paulo: Boitempo, 2004.

ZILBERMAN, R. A Literatura no Rio Grande do Sul. Porto Alegre: Mercado Aberto, 1980.

\section{Artigos de jornais e Revistas}

FERNANDES BARBOSA. Inicia-se o movimento efetivo pela Reforma Agrária. Revista Novo Horizonte palegre, 1955 (informação do local e ano de publicação informada de caneta esferográfica de tinta azul desbotada). Álbum de fotografia e recortes. In: Arquivo Nilo Fernandes Barbosa (reserva única). Doação de Ana Rita Fernandes Barbosa de Carvalho à Cachoeira do Sul-RS: Museu de Cachoeira do Sul - Patrono Edyr Lima, em 1999.

GAMA DE BEM, B. Letras da cidade em 1.964. Jornal do Povo, Cachoeira do Sul - Rio Grande do Sul, 1965.

JORNAL DO POVO. Modernismo é um retrato do túnel: só se enxerga o oco. Jornal do Povo, Cachoeira do Sul - Rio Grande do Sul, 1981.

Recebido para publicação em: 10 dez. 2020. Aceito para publicação em: 8 abr. 2021. 